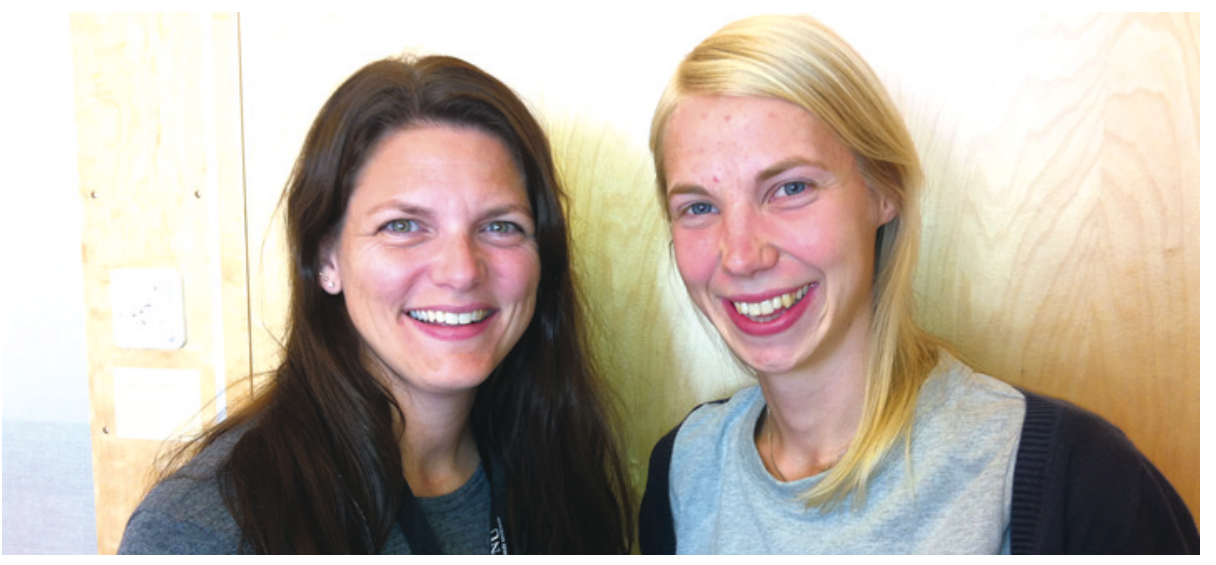

Førsteforfatter Ingrid Marie Husby (til høyre) og sisteforfatter Kari Anne Indredavik Evensen. Foto Kristine Hermansen Grunewaldt, Norges teknisk-naturvitenskapelige universitet
Ordforklaringer

Finmotorikk: Mindre bevegelser, som gjerne involverer hendene, slik som å skrive, å gripe

Grovmotorikk: Større bevegelser, som involverer store deler av kroppen

Prematuritet: Fødsel før uke 37 av svangerskapet

\title{
Prematur fødsel gir dårligere motorikk som voksen
}

Barn som blir født prematurt og med svært lav fødselsvekt har nedsatte motoriske ferdigheter som voksne.

Premature barn har større risiko for hjerneskade enn barn født til termin, og motoriske vansker er vanligere. Tidligere studier har vist at premature med svært lav fødselsvekt har dårligere fin- og grovmotorikk i barneog ungdomsalder enn barn født til termin med normal fødselsvekt. En nylig publisert norsk kasus-kontroll-studie er den første der man har undersøkt motoriske ferdigheter hos unge voksne som ble født prematurt med svært lav fødselsvekt (1).

Studien omfattet 36 unge voksne født prematurt med svært lav fødselsvekt $(<1500 \mathrm{~g})$, hvorav fire hadde cerebral parese, og 37 terminfødte kontrollpersoner med normal fødselsvekt. Deltakerne ble undersøkt ved 14 års alder og ved 23 års alder med ulike tester for å vurdere finmotorikk, ballferdigheter, balanse, grovmotoriske ferdigheter og isolert motorisk tempo. Ved 23 års alder hadde gruppen med svært lav fødselsvekt statistisk signifikant lavere skår på alle de ulike testene sammenliknet med kontrollgruppen. Mange av forskjellene var også til stede etter eksklusjon av de fire deltakerne med cerebral parese.

- Det mest gjennomgående funnet i denne studien var at gruppen med svært lav fødselsvekt var tregere motorisk enn kontrollgruppen, sier Ingrid Marie Husby, som er artikkelens førsteforfatter. Husby er forskerlinjestudent ved medisinstudiet ved Norges teknisk-naturvitenskapelige universitet, og dette er hennes første publikasjon.

- Longitudinelle analyser viste at det var like mange som hadde motoriske vansker da de var 23 år som da de var 14 år. Dette viser at de dårligere motoriske ferdighetene funnet $\mathrm{i}$ ungdomsalderen vedvarer inn i ung voksen alder. Dette kan ha konsekvenser i det voksne liv, særlig med tanke på en fysisk variert og aktiv livsstil og for valg av utdanning og yrke, sier Husby.

\section{Lav fødselsvekt i et livstidsperspektiv}

Studien er en del av et større prosjekt kalt Lav fødselsvekt i et livstidsperspektiv, som ledes av professorene Ann-Mari Brubakk og Jon Skranes. Forskningsgruppen holder til ved Institutt for laboratoriemedisin, barne- og kvinnesykdommer ved Norges teknisk-naturvitenskapelige universitet. Gruppen er tverrfaglig sammensatt av klinikere som interesserer seg for hjerneutvikling og langtidsoppfølging av barn som er født med svært lav fødselsvekt og med lav vekt i forhold til svangerskapsalder.

Artikkelens førsteforfatter er forskerlinjestudent Ingrid Marie Husby, som går på medisinstudiet i Trondheim. Studien ble planlagt og ledet av postdoktor og fysioterapeut Kari Anne Indredavik Evensen, som er sisteforfatter. Hun har drevet nevrovitenskapelig forskning på barn med svært lav fødselsvekt i 13 år og har en doktorgrad på feltet. Ann-Mari Brubakk og Jon Skranes er medforfattere av artikkelen, i tillegg til Alexander Olsen, som er ph.d.-student.

\section{Matilde Risopatron Berg}

matilde.risopatron.berg@legeforeningen.no

Tidsskriftet

\section{Litteratur}

1. Husby IM, Skranes J, Olsen A et al. Motor skills at 23 years of age in young adults born preterm with very low birth weight. Early Hum Dev 2013; 89: 747-54.
Artikkelen er publisert i tidsskriftet Early Human Development (http://www. journals.elsevier.com/early-humandevelopment/] 